\title{
Macular phlebitis in a case of dengue retinopathy
}

\author{
Sangeeta Roy, ${ }^{1}$ Brijesh Takkar, ${ }^{2}$ Rohan Chawla, ${ }^{2}$ Atul Kumar ${ }^{2}$
}

${ }^{1}$ Susrut Eye Foundation and Research Center, Kolkota, India ${ }^{2}$ Dr Rajendra Prasad Centre for Ophthalmic Sciences, All India Institute of Medical Sciences, New Delhi, India

Correspondence to Dr Brijesh Takkar, britak.aiims@ gmail.com

Accepted 15 June 2017

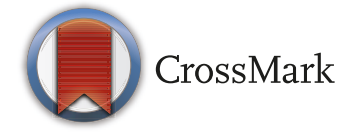

To cite: Roy S, Takkar B, Chawla $\mathrm{R}$, et al. BMJ Case Rep Published Online First: [please include Day Month Year]. doi:10.1136/bcr-2017221362

\section{DESCRIPTION}

A 32-year-old woman presented with sudden onset 1 day prior of painless diminution of vision in both eyes. The patient had developed an acute febrile illness a week prior and had been diagnosed with dengue fever (DF) after serological testing was positive. At its nadir, her platelet count had been $30000 / \mu$ L. On presentation, she was afebrile, and her platelet count was $60000 / \mu \mathrm{L}$.

On ocular examination, the best corrected visual acuity (BCVA) was 20/80 in the right eye and 20/200 in the left eye. The anterior segments and intraocular pressures were normal in both eyes. Fundus examination with slit-lamp biomicroscopy revealed perifoveal haemorrhages with scattered white-coloured exudates in the macula of both eyes (left $>>$ right). Detailed magnified examination showed perivascular exudation surrounding the postcapillary venules of the fovea along with macular oedema of both eyes (left $>>>$ right) (figure 1A, B). The patient was diagnosed with phlebitis secondary to DF.

Fundus fluorescein angiography (FFA) showed hyperfluorescence around minimally tortuous macular venules in the mid-venous phase, which increased and became diffuse in later phases suggesting dye leakage (figure 1C, D). Optical CT (OCT) showed cystoid macular oedema in both eyes (left $>$ right) along with subretinal fluid in the left eye. Central macular thickness was $213 \mu \mathrm{m}$ in the right eye and $556 \mu \mathrm{m}$ in the left eye.

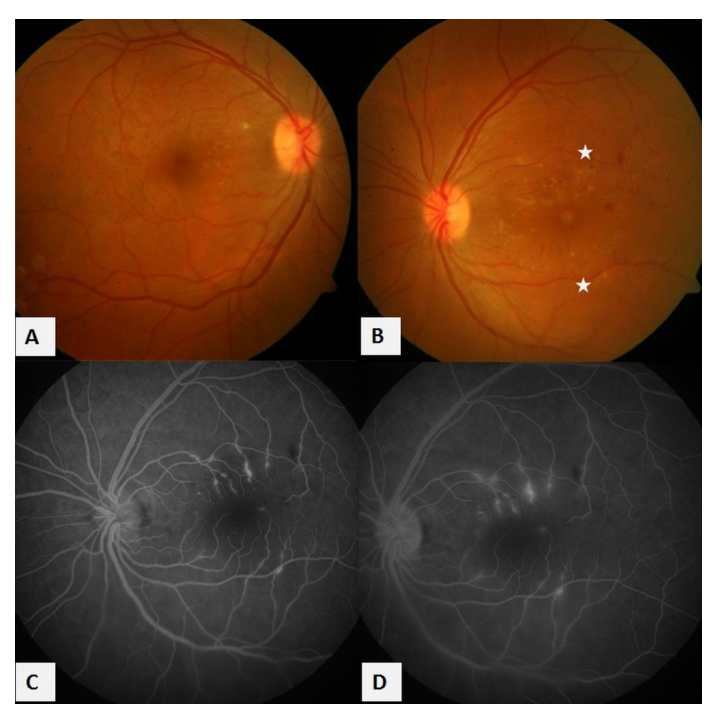

Figure $1(A, B) \quad$ Fundus photographs showing perivascular exudation (stars) and retinal haemorrhages in both eyes (LE $>>R E)$. (C,D) Fundus fluorescein angiography images of the LE showing leakage of dye due to phlebitis and minimally tortuous venules. $L E$, left eye; $R E$, right eye.

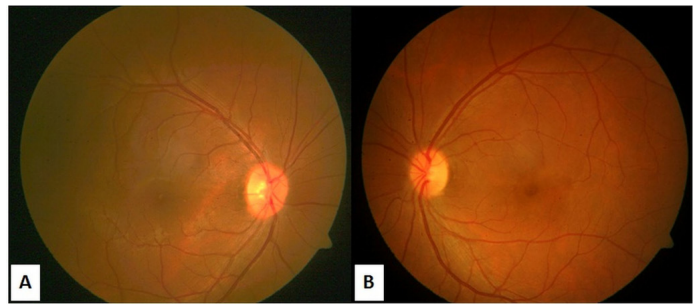

Figure 2 (A, B) Fundus photographs showing resolution of retinopathy in both eyes.

The patient was treated with oral prednisolone $(1 \mathrm{mg} / \mathrm{kg})$ in view of severe macular involvement in the left eye. On follow-up at 15 days, the BCVA had improved to $20 / 40$ in the right eye and $20 / 80$ in the left eye, and there was a resolution of macular oedema on OCT. At 1 month of follow-up, BCVA was 20/20 in both eyes, and vascular tortuosity and inflammation had resolved completely (figure 2A, B). The patient did not complain of residual scotomas. During this period, the patient remained stable systemically, and her platelet counts normalised. Her steroid dose was gradually tapered.

Ophthalmic complications of DF include anterior involvement in the form of subconjunctival haemorrhage and uveitis or posterior features like macular oedema, haemorrhages, vascular occlusion and optic neuropathy. ${ }^{1}$ Direct infection of tissue and immunocomplex-mediated disease are two possible mechanisms of ocular involvement. ${ }^{12}$ The latter is the most likely mechanism given the usual delay of 3-5 days for the onset of ocular complications, in parallel with the timeline of serological changes. ${ }^{1}$ Vein occlusion and vasculitis are the most common features detected on FFA, ${ }^{1}$ while macular oedema has been classified as diffuse, cystoid and cystic foveolitis, the latter having a longer persistence of symptoms. ${ }^{3}$ These complications can be managed conservatively, as most of the symptoms and signs regress spontaneously with normalisation of platelet counts, although scotomas can persist. Treatment is recommended only for refractory cases and those with extensive

\section{Learning points}

- Dengue fever can result in visual loss due to macular oedema secondary to macular phlebitis.

- Visual prognoses are favourable even without treatment, although extensive macular involvement may be treated with steroids. 


\section{Images in...}

vision-threatening macular complications, ${ }^{12}$ as seen in the left eye in our patient.

Contributors SR contributed to workup, diagnosis and treatment. BT contributed to imaging. SR, BT, RC and AK contributed to writing the manuscript. BT, RC and AK contributed to critical revision of the manuscript. SR and BT are overall guarantors of the data.

Competing interests None declared.

Patient consent Obtained.

Provenance and peer review Not commissioned; externally peer reviewed.
(C) BMJ Publishing Group Ltd (unless otherwise stated in the text of the article) 2017. All rights reserved. No commercial use is permitted unless otherwise expressly granted.

\section{REFERENCES}

1 Yip VC, Sanjay S, Koh YT. Ophthalmic complications of dengue fever: a systematic review. Ophthalmol Ther 2012;1:2.

2 Bacsal KE, Chee SP, Cheng CL, et alArch Ophthalmol 2007;125:501-10.

3 Teoh SC, Chee CK, Laude A, et al. Optical coherence tomography patterns as predictors of visual outcome in dengue-related maculopathy. Retina 2010;30:390-8.

Copyright 2017 BMJ Publishing Group. All rights reserved. For permission to reuse any of this content visit

http://group.bmj.com/group/rights-licensing/permissions.

BMJ Case Report Fellows may re-use this article for personal use and teaching without any further permission.

Become a Fellow of BMJ Case Reports today and you can:

- Submit as many cases as you like

Enjoy fast sympathetic peer review and rapid publication of accepted articles

Access all the published articles

Re-use any of the published material for personal use and teaching without further permission

For information on Institutional Fellowships contact consortiasales@bmjgroup.com

Visit casereports.bmj.com for more articles like this and to become a Fellow 